\title{
Molecular Evidence for the Homologous Strains of Infectious Spleen and Kidney Necrosis Virus (ISKNV) Genotype I Infecting the Inland Freshwater Cultured Asian Sea Bass (Lates Calcarifer) in Thailand
}

\section{Pattarawit Kerddee}

Kasetsart University Kamphaeng Saen Campus

\section{Nguyen Dinh-Hung}

Chulalongkorn University Faculty of Veterinary Science

\section{Ha Thanh Dong}

Suan Sunandha Rajabhat University

\section{Ikuo Hirono}

Tokyo University of Marine Science and Technology Graduate School of Marine Science and Technology: Tokyo Kaiyo Daigaku Daigakuin Kaiyo Kagaku Gijutsu Kenkyuka

\section{Chayanit Soontara}

Kasetsart University Faculty of Fisheries

\section{Nontawith Areechon}

Kasetsart University Faculty of Fisheries

\section{Prapansak Srisapoome}

Kasetsart University Faculty of Fisheries

\section{Pattanapon Kayansamruaj ( $\nabla$ pattanapon.k@ku.th )}

Kasetsart University Faculty of Fisheries https://orcid.org/0000-0002-6187-2772

\section{Research Article}

Keywords: freshwater culture, genome characterization, infectious spleen and kidney necrosis virus, Lates calcarifer, pathogenicity

Posted Date: April 19th, 2021

DOI: https://doi.org/10.21203/rs.3.rs-399227/v1

License: (c) (i) This work is licensed under a Creative Commons Attribution 4.0 International License. Read Full License 


\section{Abstract}

Infectious spleen and kidney necrosis virus (ISKNV) is the fish pathogenic virus belonging to the genus Megalocytivirus of the family Iridoviridae. In 2018, disease occurrences (40-50\% cumulative mortality) associated with ISKNV infection have been reported in grown-out Asian sea bass (Lates calcarifer) cultured in the inland freshwater system in Thailand. Clinical samples were collected from seven distinct farms located in the eastern and central regions of Thailand. The moribund fish showed various abnormal signs including lethargy, pale gill, darkened body, and skin hemorrhage, while the basophilic hypertrophied cell in gill, liver, and kidney tissue was observed microscopically. ISKNV infection was confirmed in 6 out of 7 farms using virus-specific semi-nested PCR. MCP and ATPase genes showed $100 \%$ identity among virus isolates which also classified the virus into ISKNV genotype I clade. Koch's postulates were later confirmed by challenge assay and the mortality of the experimentally infected fish at 21 days post-challenge was 50-90\% depending on the challenge dose. The complete genome of two ISKNV isolates, namely KU1 and KU2, was recovered directly from the infected specimens using the shotgun metagenomics approach. The genome length of ISKNV KU1 and KU2 were 111,487 and 111,610 bp, respectively. In comparison to the closely related ISKNV strains, the ISKNV KU1 and KU2 harbored nine unique genes, including caspase recruitment domaincontaining protein potentially involved in apoptosis inhibition. Collectively, this study indicated the homologous ISKNV strains affecting the inland cultured Asian sea bass which emphasized that the ISKNV genotype I should be prioritized for future vaccine research.

\section{Introduction}

Asian sea bass (Lates calcarifer Bloch, 1790), also known as barramundi, is a species native to Thailand and widely distributed in the Indo-West Pacific region from the Arabian Gulf to China, Taiwan, and northern Australia [14]. Asian sea bass is one of the most important marine cultured finfish in Australia and Asian countries including Indonesia, Singapore, Vietnam, and Thailand. According to its significant economic potential, this fish species has been expected by Thai governmental bodies and private sectors to be the major food fish products along with other fish species such as tilapia (Oreochromis spp.) and hybrid catfish (Clarius gariepinus $₫$ C. batrachus). The total production of Asian sea bass in Thailand was approximately 39,500 tons in 2018, increased from the year 2017 (20,500 tons) by over $90 \%$ [9]. Formerly, Asian sea bass has been cultivated mainly in the coastal area along the Gulf of Thailand and the Andaman Sea, where the fish can grow in open sea cages or brackish/marine water earthen ponds. Presently, the main practice applied for Asian sea bass grow-out has been shifted to the inland freshwater pond system, owning to the catadromous nature of the fish and the advancement of pelleted feed quality, to align with the continual increase of consumer demand [14]. Asian sea bass farming in inland freshwater in Thailand is usually applied in an intensive system. Although maximum yield can be expected with high stocking density, this aquaculture system is undeniably posing a high risk for the emergence of infectious diseases due to the stressful conditions caused by the accumulation of metabolic waste, organic matters, and fluctuation of water qualities.

Mortalities and morbidities related to the distribution of infectious diseases have been reported as the major cause of economic losses for Asian sea bass farming industry worldwide. According to the literatures, Asian sea bass are susceptible to numerous pathogen organisms including bacteria, e.g., Streptococcus iniae, Vibrio alginolyticus, Vibrio harveyi, and Photobacterium damselae subsp. damselae [2, 4, 12] and viruses such as viral nervous necrosis, Lates calcarifer herpes virus, Lates calcarifer birnavirus, and megalocytiviruses [6, 36, 38]. Among the potential virus pathogens, the members of the genus Megalocytivirus (belonging to the family Iridoviridae), such as red sea beam iridovirus (RSIV), turbot reddish body iridovirus (TRBIV), infectious spleen and kidney necrosis virus (ISKNV), and scale drop disease virus (SDDV, another distant species within the same genus) have been associated with several disease outbreaks in marine fishes in many countries, e.g., red sea bream (Pagrus major), orange-spotted grouper (Epinephelus 
coioides), olive (Japanese) flounder (Paralichthys olivaceus) and turbot (Scophthalmus maximus). The clinical signs and lesions presented in megalocytivirus-infected fish can be very diverse depending on pathogenic agents and host species. For example, fish infected with RSIV was reported showing lethargy, petechiae gills, and enlargement of the spleen [26], ISKNV-infected fish exhibited dark body, pale gills, and red eyes [11], whereas SDDV infection in Asian sea bass often correlated with extensive scale loss and skin hemorrhage lesions $[29,41]$. The occurrence of megalocytivirus infection, namely ISKNV and SDDV, were also reported as the potential pathogens causing severe mortalities of $55-77 \%$ in Asian sea bass in Thailand $[29,48]$. However, the epidemiological information and molecular characteristics of megalocytiviruses in Asian sea bass have been limited to only those observed in marine environments which is, to some extent, unsurprising since inland freshwater culture is not yet widely practiced on a global scale. To date, only one incidence of co-infection between a pathogenic bacterium Flavobacterium columnare and SDDV was reported in the freshwater system [29].

Recently, disease outbreaks occurred in the inland freshwater-based Asian sea bass grow-out farms located in the eastern and central parts of Thailand, causing mortalities ranged from 40-50\%. The initial diagnoses indicated that a series of outbreaks may involve ISKNV infection. Therefore, this study aims to investigate the molecular characteristics of these ISKNV strains and their pathogenic roles on Asian sea bass reared in a freshwater system. In addition, the genome of the virus was also examined using a metagenomic approach which, to our knowledge, was the first ISKNV genome from a freshwater cultured Asian sea bass ever sequenced.

\section{Materials And Methods}

\section{Disease history and sample collection}

Fish farmers reported the occurrence of unknown diseases in Asian sea bass in seven freshwater grow-out farms located in Samut Sakhon, Samut Songkhram, and Chachoengsao provinces, Thailand, between February and November 2018. Diseased fish was ranged from 20 to $30 \mathrm{~g}$ in weight. The cumulative mortality varied from 40 to 50 percent (as monitored by farm's practitioners). Moribund fish was euthanized by decerebration and bacterial isolation was carried out on-site. Internal organs (kidney, spleen, and liver) of each individual were collected separately, preserved in $95 \%$ ethanol for PCR testing, and delivered on-ice to the laboratory within $4 \mathrm{hr}$. Ethanol-fixed tissues were maintained in a $-20^{\circ} \mathrm{C}$ refrigerator until further PCR assay, whereas fresh tissues for virus isolation were preserved at $-80^{\circ} \mathrm{C}$. On the part of histopathology, collected tissue from sacrificed fish was immersed in $10 \%$ neutral buffered formalin at a ratio of $1: 10(\mathrm{w} / \mathrm{v})$ for $24-36 \mathrm{hr}$, followed by replacement with the same volume of $70 \%$ ethanol for longterm preservation. Preserved tissue samples were processed for standard histological analysis by dehydration, embedded with paraffin, and sectioned followed by staining with hematoxylin and eosin (H\&E) [21]. The H\&E-stained tissues were then examined under a light microscope equipped with a digital camera. The negative control used for further assays was the apparently healthy Asian sea bass obtained from a different location. The animal use protocol conducted in this study was approved by the Institutional Animal Care and Use Committee, Faculty of Fisheries, Kasetsart University (permit ID: ACKU61-FIS-055).

\section{Bacterial isolation and identification}

Direct isolation from external lesions (gills and skin) and internal organs (spleen, kidney, and liver) was conducted using two different media comprised of (i) tryptic soy agar (TSA, Himedia, India) supplemented with $5 \%$ sheep blood using as a generalized medium, (ii) Anacker and Ordal agar (AOA, tryptone $0.5 \mathrm{~g} / \mathrm{L}$, yeast extract $0.5 \mathrm{~g} / \mathrm{L}$, sodium acetate $0.2 \mathrm{~g} / \mathrm{L}$, beef extract $0.2 \mathrm{~g} / \mathrm{L}$, and agar $10 \mathrm{~g} / \mathrm{L}$ ) supplemented with $1 \mu \mathrm{g} \mathrm{mL}^{-1}$ tobramycin (Sigma-Aldrich, Singapore) using as a selective medium for Flavobacterium sp. [44]. Streaked plates were delivered to the laboratory 
then inoculated at $28^{\circ} \mathrm{C}$ until bacterial colonies were visible $(24-48 \mathrm{~h})$. Colonies were sub-cultured using the same kind of medium until a pure colony was obtained. Pure colonies grown on either TSA or AOA medium were subjected to preliminary identification of bacterial identity using Gram staining and primary biochemical assays including oxidase, catalase, oxidation-fermentation, and motility tests. Bacterial taxonomy was determined to the genus level based on Cowan and Steel's manual [7].

\section{Identification of ISKNV infection from tissue samples DNA extraction from fish tissues}

Screening of ISKNV infection was carried out for every individual fish collected in this study $(n=26)$. To extract DNA, tissue was removed from ethanol and homogenized using disposable polypropylene pestles. DNA was extracted using Tissue Genomic DNA Extraction Mini Kit (Geneaid, Taiwan) according to the manufacturer's instructions. DNA concentration was quantified using a Nanodrop analyzer (Titertek Berthold, Germany) and stored at $-20^{\circ} \mathrm{C}$.

\section{PCR identification for ISKNV}

ISKNV-specific primers (Table 1) were used for screening of the infection by one-tubed semi-nested PCR (snPCR) [11]. Each $25 \mu \mathrm{L}$ PCR mixture contained 1X master Mix (Go-Taq®-Green, Promega USA), $10 \mathrm{nM}$ of each working primers, and $100 \mathrm{ng}$ of DNA template. The thermal condition was $94^{\circ} \mathrm{C}$ for $3 \mathrm{~min}$ followed by 35 cycles of $94^{\circ} \mathrm{C}$ for $30 \mathrm{~s}, 65^{\circ} \mathrm{C}$ for $30 \mathrm{~s}, 72^{\circ} \mathrm{C}$ for $1 \mathrm{~min}$ and final extension at $72^{\circ} \mathrm{C}$ for $5 \mathrm{~min}$. PCR products were analyzed by $1 \%$ agarose gel electrophoresis followed by staining with Red Safe (Chembio, UK) and visualized under UV light. Expected PCR products from positive ISKNV samples were either one amplicon of $164 \mathrm{bp}$, two amplicons at 517 and $164 \mathrm{bp}$, or three amplicons at 754, 517, and 164 bp representing light, moderate and heavy infections, respectively, as described in the original article [11]. We used a positive control from DNA template extracted from ISKNV-infected sample kindly provided by Centex, Mahidol University, whereas healthy Asian sea bass and nuclease-free water without DNA template served as the internal and negative control, respectively. 
Table 1

Primers used in this study.

\begin{tabular}{|c|c|c|c|c|}
\hline $\begin{array}{l}\text { Primer } \\
\text { name }\end{array}$ & Primer sequence $\left(5^{\prime}-3^{\prime}\right)$ & Feature & $\begin{array}{l}\text { Product } \\
\text { size } \\
\text { (bp) }\end{array}$ & References \\
\hline \multicolumn{5}{|c|}{ ISKNV screening by one-tubed semi-nested PCR } \\
\hline Megalo-F & AGATGATTGGCATGCGCAGCG & \multirow{4}{*}{$\begin{array}{l}\text { Semi-nested PCR targeting } \\
M C P \text { gene for ISKNV screening }\end{array}$} & 754 & \multirow[t]{4}{*}{ [11] } \\
\hline $\begin{array}{l}\text { Megalo- } \\
1 \mathrm{R}\end{array}$ & TTGGACAGGCGGCCGTAGT & & & \\
\hline $\begin{array}{l}\text { Megalo- } \\
\text { 2Rsn }\end{array}$ & TACACGGGACTGGCCGC & & 517 & \\
\hline $\begin{array}{l}\text { Megalo- } \\
\text { 3Rsn }\end{array}$ & CTTGAAGTGGATGCGCACCTC & & 164 & \\
\hline \multicolumn{5}{|c|}{ ISKNV sequencing } \\
\hline MMCP-F & ATGTCTGCRATCTCAGGT & \multirow[t]{2}{*}{ Sequencing of $M C P$ gene } & 1362 & \multirow[t]{4}{*}{ [20] } \\
\hline MMCP-R & TYACAGGATAGGGAAGCCTG & & & \\
\hline $\begin{array}{l}\text { MATPase- } \\
\text { F }\end{array}$ & ATGGAAATCMAAGAGTTGTCCYTG & \multirow[t]{2}{*}{ Sequencing of $A T P a s e$ gene } & 720 & \\
\hline $\begin{array}{l}\text { MATPase- } \\
\mathrm{R}\end{array}$ & TTACRCCACGCCAGCCTTGTA & & & \\
\hline \multicolumn{5}{|c|}{ ISKNV qPCR } \\
\hline $\begin{array}{l}\text { Meg- } \\
\text { MCP160F }\end{array}$ & TCAAAACAGACTGGCCATGC & \multirow[t]{3}{*}{$\begin{array}{l}\text { qPCR targeting MCP gene for } \\
\text { quantifying ISKNV }\end{array}$} & \multirow[t]{3}{*}{190} & \multirow{3}{*}{$\begin{array}{l}\text { Kawato 2021, } \\
\text { submitted } \\
\text { paper }\end{array}$} \\
\hline $\begin{array}{l}\text { Meg- } \\
\text { MCP349R }\end{array}$ & TAAATGACACCGACACCTCCTC & & & \\
\hline $\begin{array}{l}\text { Meg- } \\
\text { MCP239P }\end{array}$ & $\begin{array}{l}\text { 6-FAM-FAM-TGTGGCTGCGTGTTA } \\
\text { AGATCCCCTCCA-BHQ-1 }\end{array}$ & & & \\
\hline
\end{tabular}

\section{Sequencing analysis of viral MCP and ATPase genes DNA sequencing of MCP and ATPase genes}

Asian sea bass DNA extracts giving positive PCR results for ISKNV screening based on the one-tubed snPCR were further used for phylogenetic analysis. ISKNV positive sample was selected randomly (only one sample per farm) and DNA was extracted from the liver. Two ISKNV genes, encoded for MCP and ATPase, were targeted for sequence analysis. The detail of each primer set is shown in Table 1. The PCR conditions followed those described in the original article [20]. Amplicons were purified following agarose gel electrophoresis using a Universal DNA purification kit (Tiangen, Beijing, China) according to the manufacturer's instruction. The purified DNA fragments were ligated into pGEM-T Easy cloning vector (Promega, WI, USA) and transformed to Escherichia coli JM109 competent cells as described by Russell and Sambrook [40]. Transformants were selected using Luria-Bertani agar (LB, Oxoid, UK) containing selective antibiotic and subsequently multiply in LB broth prior to plasmid isolation using NucleoSpin ${ }^{8}$ Plasmid MiniPrep kit (Macherey-Nagel, Germany). The extracted plasmid was submitted for Sanger sequencing at sequencing laboratory service (1st BASE Pte Ltd., Malaysia) using pUC/M13 primers as described in Promega's pGEM$T$ vector manual. 


\section{Phylogenetic analysis}

Low-quality bases were trimmed manually based on a chromatogram of the raw sequences. Trimmed sequences were then assembled into contig using ContigExpress. The homology search was performed using Megablast against NCBI's nucleotide database to align and compared to the other ISKNV strains. MCP and ATPase genes of the ISKNV of this study ( $n=6$, one sample per farm) were compared to other members of the genus Megalocytivirus including ISKNV $(n=11-22)$, RSIV, $(n=22-43)$, and TRBIV $(n=7-14)$. Nucleotide sequences were aligned using ClustaIW, then the phylogenetic tree was constructed using the maximum likelihood method with $G T R+G+$ I substitution model and 1000 bootstrap replicates. Multiple sequence alignment and phylogenetic reconstruction were carried out using MEGAX software [31].

\section{Genome analysis}

\section{Library preparation and next-generation sequencing}

Two samples with possibly severe ISKNV infection (one-tubed snPCR yielded three distinct amplicons as described in the previous section) from Samut Sakhon province were used for the metagenomic shotgun sequence. The Nextera XT library preparation kit (Illumina, CA, USA) was used to construct a paired-end library from the extracted genomic DNA according to the manufacturer's instruction. Subsequently, high throughput sequencing was performed using Illumina HiSeq system with 150-bp read length. Library construction and sequencing were carried out using the service provided by Novogene (Beijing, China).

\section{ISKNV genome reconstruction and annotation}

Processing of raw reads and de novo assembly was conducted as described in our previous publication [28]. The adaptor sequences and low-quality reads were filtered out from raw reads using Trimmomatic v0.39 [3]. Then, hostderived reads were discarded by mapping trimmed reads against Asian sea bass reference genome (NCBI assemblies accession no. GCA_001640805.1) using -x function in the Bowtie2 program [33]. The obtained non-host reads were subjected to de novo metagenome assembly using MEGAHIT v 1.2.9 with a minimum length of output contigs of 1000 bp [34]. The generated assemblies were submitted to the web server version of the Kaiju program to predict the taxonomic identity of each contig [37]. Contigs being assigned as ISKNV were annotated using Prokka v1.14.0 with Viruses Annotation mode and the complete ISKNV reference genome (Genbank accession no. NC_003494.1) was selected as annotation template. The name 'ISKNV KU1 and KU2' were assigned to these ISKNV-like contigs observed in our two samples, respectively. Visualization of the ISKNV KU1 and KU2 as a circular genome map was performed by uploading the annotated genomes to the web server version of CGview (http://cgview.ca/) [16].

\section{Phylogenomic analysis and genome distance}

ISKNV KU1 and KU2 were aligned to the ISKNV reference genome using MAUVE progressive alignment [8]. The genome segments of ISKNV KUs were rearranged manually following with the ISKNV reference genome. To determine genetic distance, multiple alignment of the megalocytiviruses, including ISKNV KUs, was performed using the FFT-NS-i method in MAFFT v7 online service [25] and MEGA-X was used to calculate the distance based on the Maximum Composite Likelihood model. The phylogenomic network was generated using SplitsTree4 based on the alignment of megalocytivirus genomes [22].

\section{Identification of orthologous groups}

OrthoFinder [13] was used to determine the possible orthologs among four ISKNV genomes, including two ISKNV strains of this study (KU1 and KU2) and two closely related strains (RSIV-Ku and ISKNV reference strain). The coding 
sequences (CDSs) of strain RSIV-Ku and reference genome were obtained from GenBank under the accession nos. KT781098 and NC_003494, respectively. OrthoFinder pipeline automatically categorizes the proteins from tested subjects into orthologous groups (also called orthogroups) based on sequence similarity. In this study, proteins of ISKNV KU1 and KU2 predicted as 'non-orthologous' comparing to the reference strain and RSIV-Ku were subjected for further protein Blast analysis.

\section{Propagation of ISKNV using GF cell line}

ISKNV isolate KU1 was used for virus isolation. One gram $(1 \mathrm{~g})$ of liver and spleen preserved at $-80 \mathbb{C}$ was pooled and homogenized in $10 \mathrm{ml}$ of L15 medium (Gibco, CA, USA) followed by centrifugation at $9600 \times \mathrm{g}$ for $30 \mathrm{~min}$ at $4^{\circ} \mathrm{C}$. After centrifugation, the supernatant was collected and filtered with a sterile $0.22 \mu \mathrm{m}$ membrane filter. Filtrate $(0.5 \mathrm{~mL})$ was inoculated in a $5 \mathrm{~mL}$ flask of monolayer Grunt fin (GF) cells for 2 hours, and the medium was replaced with fresh L15 medium supplemented with $10 \%$ FBS (Gibco, CA, USA). The flasks were then incubated at $25^{\circ} \mathrm{C}$ and observed under a microscope daily for 10 days to monitor the cytopathic effect (CPE). The virus was harvested by centrifugation of cell culture supernatant at $1000 \times \mathrm{g}$ for 5 minutes at $4^{\circ} \mathrm{C}$. Cell debris was discarded and the supernatant containing ISKNV was collected and preserved in $\mathrm{a}-80^{\circ} \mathrm{C}$ refrigerator until used in the experimental challenge.

The calculation viral copy number of ISKNV in viral suspension was conducted using qPCR specific to ISKNV (Kawato 2021 , submitted paper). One hundred and forty microlitres $(140 \mu \mathrm{l})$ of the supernatant was used for DNA extraction using the phenol-chloroform method. The qPCR reaction consisted of 1X iTaq Universal Probes Supermix (Bio-Rad), 3 $\mu \mathrm{L}$ of DNA template, $900 \mathrm{nM}$ of each forward and reverse primers (Meg-MCP160F and Meg-MCP349R) and $250 \mathrm{nM}$ of Meg-MCP239P probe in a total volume of $20 \mu \mathrm{L}$. The qPCR condition was an initial denaturation at $95^{\circ} \mathrm{C}$ for $10 \mathrm{~min}$ followed by 40 cycles of $95^{\circ} \mathrm{C}$ for $15 \mathrm{~s}$ and $64^{\circ} \mathrm{C}$ for $1 \mathrm{~min}$. Both viral detection protocols were run using Bio-Rad CFX Connect RealTime PCR machine, which product size from this qPCR is $190 \mathrm{bp}$.

\section{Pathogenicity test}

The healthy Asian sea bass $(n=150)$ was used in the experimental challenge test to fulfill Koch's postulate. The fish with an average weight of $22 \mathrm{~g}$ were purchased from a local grow-out farm. Five fish were randomly sampled to verify the ISKNV-free status from splenic tissue using virus-specific one-tube snPCR as described above. ISKNV free fish were used for pathogenicity tests following a week of acclimatization in a 3,000-L tank. Fish were divided into three groups ( $n=50$ per group) comprising one control group and two challenge groups. A group served as control received sterile cell culture medium, whereas challenge groups were injected intraperitoneally by a volume of $0.2 \mathrm{ml}$ containing the propagated virus of different dilutions (low dose [ $10^{-2}$ dilution] and high dose [non-diluted]). Injected fish was transferred into aerated 500 - $\mathrm{L}$ tanks $(\mathrm{n}=50$ per tank) with the water temperature and dissolved oxygen maintained at $30-32^{\circ} \mathrm{C}$ and $5-7 \mathrm{ppm}$, respectively. Freshly dead and moribund fish was removed from the tank on notice. The liver, spleen, and kidney of affected fish were collected for histopathological investigation and ISKNV screening using onetubed snPCR. Daily mortality was recorded for 21 days and the Kaplan-Meier survival curve with the logrank statistical test was carried out using the IBM SPSS Statistics 25 program.

\section{Results}

\section{Clinical manifestations of naturally infected fish}

The observed losses in grow-out Asian sea bass varied from 40 to $50 \%$ within 1-2 weeks after the disease was noticed. The moribund fish manifested clinical signs such as lethargy and anorexia, while the external lesions including darkened body, pale gill, skin hemorrhage, and ascites were also observed. Internally, swollen spleen and hemorrhage at liver and trunk kidney were the most abundant lesions (Fig. 1). Histopathological manifestations 
included severe hemorrhage, inflammatory cell infiltration, accumulation of melanocytes, extensive necrosis at the skin and gill, and moderate tubular degeneration in the trunk kidney (Fig. 2A). Interestingly, the typical microscopic lesions representing viral infection, namely eosinophilic inclusion, and the hallmark histological changes for ISKNV infection, i.e., basophilic hypertrophied cells, were also detected in gill, liver, and kidney.

Bacterial isolation was attempted from necrotic gills and skin lesions using Flavobacterium-selective medium, AOA, whereas generalized medium, TSA, was applied to internal organs with apparent lesions. Bacterial colonies grown on the AOA medium showed yellowish and rhizoid morphology. The detail of collected fish samples and the observed lesions, coupled with the disease diagnostic results, were summarized in Table 2. 
Table 2

Summary of diseased Asian sea bass samples collected in this study.

\begin{tabular}{|c|c|c|c|c|c|c|c|c|c|}
\hline \multirow[t]{2}{*}{$\begin{array}{l}\text { Month } \\
\text { (2018) }\end{array}$} & \multirow[t]{2}{*}{ Province } & \multirow[t]{2}{*}{ Farm } & \multirow[t]{2}{*}{$\begin{array}{l}\text { Macroscopic } \\
\text { lesions }\end{array}$} & \multirow[t]{2}{*}{$\begin{array}{l}\text { Microscopic } \\
\text { lesions }\end{array}$} & \multicolumn{4}{|c|}{$\begin{array}{l}\text { Bacterial } \\
\text { identification }\end{array}$} & \multirow{2}{*}{$\begin{array}{l}\text { ISKNV } \\
\text { identification' } \\
\text { (no. of } \\
\text { infected } \\
\text { samples) }\end{array}$} \\
\hline & & & & & $\mathrm{Ae}$ & $\mathrm{FI}$ & Str & Ed & \\
\hline \multirow[t]{2}{*}{ February } & \multirow[t]{2}{*}{ Chachoengsao } & $A$ & $\begin{array}{l}\text { Darkened } \\
\text { body, pale } \\
\text { gill }\end{array}$ & $\begin{array}{l}\text { Gill necrosis, } \\
\text { inflammation } \\
\text { and } \\
\text { melanocyte } \\
\text { aggregation } \\
\text { in muscle }\end{array}$ & ND & ND & ND & ND & $+(6 / 7)$ \\
\hline & & $B$ & Inapparent & ND & ND & ND & ND & ND & $-(0 / 4)$ \\
\hline \multirow[t]{2}{*}{ June } & \multirow[t]{2}{*}{ Chachoengsao } & $\mathrm{C}$ & $\begin{array}{l}\text { Skin and } \\
\text { liver } \\
\text { hemorrhage, } \\
\text { pale gill }\end{array}$ & $\begin{array}{l}\text { Skin } \\
\text { hemorrhage, } \\
\text { muscle } \\
\text { inflammation, } \\
\text { tubular } \\
\text { degeneration, } \\
\text { and } \\
\text { cytoplasmic } \\
\text { inclusion } \\
\text { bodies in } \\
\text { kidney }\end{array}$ & + & + & - & - & $+(3 / 3)$ \\
\hline & & D & $\begin{array}{l}\text { Skin } \\
\text { hemorrhage, } \\
\text { eye bleeding }\end{array}$ & $\begin{array}{l}\text { Muscle } \\
\text { inflammation, } \\
\text { tubular } \\
\text { degeneration } \\
\text { at kidney }\end{array}$ & - & + & - & - & $+(3 / 4)$ \\
\hline \multirow[t]{2}{*}{ August } & \multirow[t]{2}{*}{ Samut Sakhon } & $E$ & Inapparent & ND & - & ND & - & - & $+(3 / 3)$ \\
\hline & & $\mathrm{F}$ & Inapparent & ND & - & ND & - & - & $+(1 / 1)$ \\
\hline November & Samut Prakan & G & $\begin{array}{l}\text { Ascites, } \\
\text { darkened } \\
\text { body, Scale } \\
\text { loss, pale gill }\end{array}$ & $\begin{array}{l}\text { Necrosis and } \\
\text { cellular } \\
\text { proliferation } \\
\text { at gill, muscle } \\
\text { inflammation, } \\
\text { kidney } \\
\text { degeneration }\end{array}$ & - & + & - & - & $+(4 / 4)$ \\
\hline \multicolumn{10}{|c|}{$\begin{array}{l}\text { a Flavobacterium sp. was presumptively diagnosed based on the appearance of yellowish and rhizoid colonies } \\
\text { grown on Flavobacterium-specific medium, AOA, whereas other bacteria were classified to the genus level based } \\
\text { on biochemical analyses according to Cowan and Steel's manual [7]. }\end{array}$} \\
\hline \multicolumn{10}{|c|}{$\begin{array}{l}\text { b ISKNV identity was identified based on virus-specific one-tubed semi-nested PCR from liver and spleen } \\
\text { specimens [11]. }\end{array}$} \\
\hline
\end{tabular}

\section{Identification of ISKNV}

Infection of ISKNV in Asian sea bass samples was primarily screened using one-tubed snPCR targeting $M C P$ gene. Out of 26 fish collected in this study, 20 were positive to ISKNV detection ( 6 out of 7 farms). Despite the samples of the same origin (farm), the degree of infection, as interpreted by the number of amplicons, varied among positive samples. The electrophoresis photographs are demonstrated in the supplementary Figure S1. According to the original study 
mentioning the semi-quantitative nature of one-tubed snPCR [11], relatively high, moderate, and low viral copy numbers would appear as three, two, and one amplicon on agarose gel electrophoresis, respectively.

\section{Phylogenetic analysis based on MCP and ATPase genes}

Amplification of MCP and ATPase genes was conducted from 6 samples (one per farm) diagnosed as ISKNV positive (Supplementary figure S2). The nucleotide sequences of the almost complete $M C P(1,275 \mathrm{bp})$ and complete ATPase (720 bp) genes were identical (100\% identity) among the ISKNV isolates of this study. Therefore, we submitted both MCP and ATPase genes from only a single ISKNV isolate to the GenBank database under the accession nos.

MW269579 and MW269580, respectively. Blast analysis of MCP and ATPase genes indicated that the ISKNV obtained in this study was also identical to several ISKNV strains available in NCBI's nucleotide database such as AFIV-16 (MK689685) and ISKNV strain RSIV-Ku (KT781098). The reconstruction of phylogenetic trees based on MCP and ATPase genes of ISKNV, RSIV, and TRBIV (virus species in the genus Megalocytivirus) was demonstrated in Figs. 3A and $3 \mathrm{~B}$. According to the $M C P$-based tree, ISKNV isolates were clustered into two different subclades, corresponding to the genotype I and II. Herein, the ISKNV of this study fell into genotype I. On the contrary, sub-clustering among ISKNV isolates were unclear in the ATPase-based tree which could be due to the lower number of taxa.

\section{Genome features}

Asian sea bass samples from farm E and $\mathrm{F}(n=2)$ in Samut Sakhon province with relatively high viral load (as shown by one-tubed sn PCR) was selected for metagenomics shotgun sequencing. Non-host reads were de novo assembled into 1,482 and 1,030 contigs, respectively. Taxonomic identification by the Kaiju web server indicated that, from each sample, only the longest contig was predicted as ISKNV. The length (111 kb) and GC content (54.8\%) of these contigs were almost identical to the ISKNV reference genome. These virus strains were named 'ISKNV KU1' and 'ISKNV KU2', and the summarization of their genomics characteristics is shown in Table 3. Both ISKNV genomes were submitted to GenBank under the accession nos. MT128666 and MT128667. Their genome map is visualized in Fig. 4.

Table 3

Genome features of ISKNV KU1 and 2 compared to those of reference genome

\begin{tabular}{|llll|}
\hline & ISKNV KU1 & ISKNV KU2 & ISKNV reference strain \\
\hline Genbank accession numbers & MT128666 & MT128667 & NC_003494 \\
\hline Genome length & $111,487 \mathrm{bp}$ & $111,610 \mathrm{bp}$ & $111,362 \mathrm{bp}$ \\
\hline Number of contigs (coverage depth) & $1(47 \rrbracket)$ & $1(56 \rrbracket)$ & 1 (na) \\
\hline GC content & $54.8 \%$ & $54.8 \%$ & $54.8 \%$ \\
\hline Number of genes & $122^{\mathrm{a}}$ & $123^{\mathrm{a}}$ & 125 \\
\hline Host & Asian sea bass, Lates & Asian sea bass, Lates & Mandarin fish, \\
calcarifer & 9 Siniperca chuatsi \\
\hline $\begin{array}{l}\text { Nucleotide identity compared to the } \\
\text { reference genome }\end{array}$ & $99.98 \%$ & $99.98 \%$ & na \\
\hline a Number of genes were predicted by Prokka v 1.14 .0 & & \\
\hline na, Not applicable & & & \\
\hline
\end{tabular}

Phylogenomic analysis 
The neighbor-net network analysis was able to differentiate 15 members of the genus Megalocytivirus into three distinct clusters, namely RSIV, TRBIV, and ISKNV groups (Fig. 3C). The genomes of ISKNV KU1 and KU2 were almost identical to those of the ISKNV reference strain and RSIV-Ku strain with minimal genome distances of $0.02 \%$ and $0.06 \%$, respectively. On the contrary, the genome distance between distinct clusters can be as high as $5.5-9.4 \%$. The reticulation pattern was clearly observed among the ISKNV and RSIV groups which indicated the possible genetic recombination within this cluster.

\section{Orthology between ISKKNV KU1, KU2, and reference strains}

OrthoFinder categorized a total of 499 genes, obtained from four distinct ISKNV strains (KU1, KU2, RSIV-Ku, and reference strain), into 124 orthogroups. Among these, 88 orthogroups (70.9\%) were presented in all ISKNV strains. The RSIV-Ku and reference strains possessed 13 and 18 genes that were unassigned to any orthogroups (unique genes). Seven orthogroups can be found exclusively in the strain KU1 and KU2, but absent in the other two ISKNV strains. The strain KU1 also carried two genes that unique to its genome. Most of these KU1- and KU2-specific genes were predicted as hypothetical proteins-encoded and similar to other viruses in the genus Megalocytivirus, such as Angelfish iridovirus AFIV-16, scale drop disease virus, Banggai cardinalfish iridovirus, and Red sea bream iridovirus. There was one protein from KU1 (QQZ00456) and KU2 (QQZ00673) strain that almost identical to the caspase recruitment domain-containing (CARD) protein of the Angelfish iridovirus AFIV-16. The details of these nine genes presented only in the stains KU1 and KU2 are demonstrated in Table 4, coupled with the Blast protein analysis result.

Table 4

The ISKNV strain KU1 and KU2 protein non-orthologous ${ }^{a}$ to the ISKNV RSIV-Ku and reference strain

\begin{tabular}{|c|c|c|c|c|c|c|}
\hline \multicolumn{2}{|l|}{ Protein ID } & \multirow{2}{*}{$\begin{array}{l}\text { Length } \\
\text { (aa) }\end{array}$} & \multirow[t]{2}{*}{ Best protein BLAST hit } & \multirow{2}{*}{$\begin{array}{l}\text { Accession } \\
\text { number }\end{array}$} & \multirow{2}{*}{$\begin{array}{l}\text { Query } \\
\text { coverage, } \\
\text { Identity } \\
(\%)\end{array}$} & \multirow{2}{*}{$\begin{array}{l}\mathrm{E}- \\
\text { value }\end{array}$} \\
\hline KU1 & KU2 & & & & & \\
\hline QQZ00456.1 & QQZ00673.1 & 101 & $\begin{array}{l}\text { Caspase recruitment domain- } \\
\text { containing protein [Angelfish } \\
\text { iridovirus AFIV-16] }\end{array}$ & QIQ54447.1 & $\begin{array}{l}\text { 100, } \\
99.01\end{array}$ & $\begin{array}{l}5.00 \mathrm{E}- \\
68\end{array}$ \\
\hline QQZ00464.1 & QQZ00681.1 & 80 & $\begin{array}{l}\text { Hypothetical protein [Scale drop } \\
\text { disease virus] }\end{array}$ & QLI60734.1 & $86,37.84$ & $\begin{array}{l}5.00 \mathrm{E}- \\
06\end{array}$ \\
\hline QQZ00514.1 & QQZ00609.1 & 122 & $\begin{array}{l}\text { Hypothetical protein [Banggai } \\
\text { cardinalfish iridovirus] }\end{array}$ & QOE77200.1 & 100,100 & $\begin{array}{l}6.00 \mathrm{E}- \\
84\end{array}$ \\
\hline QQZ00518.1 & QQZ00613.1 & 97 & Not found & - & - & - \\
\hline QQZ00523.1 & QQZ00618.1 & 158 & $\begin{array}{l}\text { ORF068 [Angelfish iridovirus } \\
\text { AFIV-16] }\end{array}$ & QIQ54512.1 & 100,100 & $\begin{array}{l}1.00 \mathrm{E}- \\
115\end{array}$ \\
\hline QQZ00536.1 & QQZ00631.1 & 34 & Not found & - & - & - \\
\hline QQZ00568.1 & QQZ00663.1 & 95 & Not found & - & - & - \\
\hline QQZ00479.1 & - & 316 & $\begin{array}{l}\text { ORF025 [Angelfish iridovirus } \\
\text { AFIV-16] }\end{array}$ & QIQ54469.1 & $\begin{array}{l}100 \\
61.59\end{array}$ & $\begin{array}{l}3.00 \mathrm{E}- \\
37\end{array}$ \\
\hline QQZ00505.1 & - & 63 & $\begin{array}{l}\text { Hypothetical protein ORF050 } \\
\text { [Red seabream iridovirus] }\end{array}$ & & $\begin{array}{l}100 \\
93.65\end{array}$ & $\begin{array}{l}3.00 \mathrm{E}- \\
30\end{array}$ \\
\hline
\end{tabular}


In vitro replication of ISKNV was carried out by propagating the virus in the GF cell line. ISKNV KU1 was selected as the source of the virus seed. At $25^{\circ} \mathrm{C}$, the on-set for CPE was 5 days in which focal degeneration of GF cell can be observed by the limited area of cell detachment and cell shrinkage, inferring pyknosis (Fig. 5, top-right panel). At 7 days, vacuolization and pyknosis were observed throughout the confluent monolayer suggesting severe degeneration of host cells (Fig. 5, bottom-right panel). On the contrary, no CPE change was found in GF cells propagated with sterile L15 medium until the end of the culture period of 10 days. Cell culture supernatant was harvested from both control and virus-infected cells at 7 days post-inoculation (dpi) and genomic DNA was extracted. This DNA was used as a template in ISKNV-specific one-tubed snPCR and the result indicated the specific amplification only from the ISKNVinfected cells (Supplementary Figure S3). The ISKNV-specific qPCR indicated that the viral copy number of viral stocks for challenge assay was $1.45 \otimes 10^{6}$ copies $/ \mathrm{mL}$.

\section{Viral pathogenicity assay}

The healthy Asian sea bass reared in freshwater was challenged intraperitoneally with GF-cell grown ISKNV at the dosage of $2.9 \otimes 10^{5}$ (high dose) or $2.9 \otimes 10^{3}$ (low dose) copies/fish. Mortality on-set for high dose and low dose groups was at 5- and 8-days post-challenge (dpc), respectively. Daily mortality in both high and low dose groups was 1-3 fish per day, except for 18 and $19 \mathrm{dpc}$ in which 5-8 dead fish was monitored in the high dose group. In the low dose group, mortality has stopped at $19 \mathrm{dpc}$. The cumulative mortality at the end of the experiment (21 dpc) was $90 \%$ on the high dose group (45 out of 50 fish), significantly higher than those observed in the low dose group [50\%, 25 out of 50 fish $(p<0.05)$ ]. The experimentally infected fish was found positive to one-tubed snPCR. These infected fish samples yielded three specific amplicons suggesting relatively high viral load present in the liver (Supplementary Figure S4). Herein, two fish in the control group (4\%) died a day after mock infection, which could be due to injection injury since one-tubed snPCR showed negative results. The survival curve is demonstrated in Fig. 6.

The challenged fish showed clear pathological changes similar to the naturally infected fish. Externally, moribund fish exhibited darkened bodies with pale gills. Microscopically, hematopoietic tissues showed apoptosis (pyknotic nuclei) and cytoplasmic inclusion bodies, whereas tubular degeneration was found in the kidney, and gill lamellar showed basophilic hypertrophied cell (Fig. 2C and 2D).

\section{Discussion}

Nowadays, most of the Asian sea bass culture in Thailand has been conducted using an inland freshwater culture system, in response to the continual increase of consumer demand. According to our observation (unpublished data), the former cage culture system in the estuary has been considered by Asian sea bass farmers as a risky practice due to the unmanageable biosecurity and water qualities. The major cultivation area of grown-out Asian sea bass in Thailand, to date, is in the central and eastern regions due to the availability of fingerling supplies and abundant water resources. Moreover, the Asian sea bass farming area is expected to be on the rise since this fish species has been appraised, by the governmental bodies and private sectors in Thailand, as valuable fisheries products for future exportation. However, intensive farming would induce stress responses due to the overstocking and overfeeding which resulted in the increase disease vulnerability, possess a risk for severe disease outbreaks. In this study, ISKNV was identified from diseased Asian sea bass cultured in the inland freshwater system. The most common histopathological lesions from ISKNV-infected Asian sea bass collected in this study, i.e., severe necrosis and the appearance of basophilic inclusion bodies in gills, liver, and kidney, was consistent with the pathognomonic lesions of megalocytivirus infection (hypertrophy/megalocytosis in gill and liver) reported previously [32, 45]. In this study, the histopathological manifestations in the spleen, kidney, and liver also suggested the viral tropisms in these hematopoietic organs which, to some extent, may result in immune incompetent/suppression and increased 
susceptibility to opportunistic infections. Co-infection between Flavobacterium columnare and SDDV, another member of the genus Megalocytivirus, in grown-out Asian sea bass has been reported in our previous investigation [29]. Considering that ISKNV and the potential bacterial pathogens, such as Aeromonas sp., Streptococcus sp., and Flavobacterium sp., was co-identified from 3 out of 7 disease incidences in this study, it is feasible that simultaneous infection is relatively common among natural disease occurrences in Asian sea bass. Simultaneous infection, also called a concurrent infection, can be found often in farmed fish and could outweigh a single infection [10]. In our case, we speculated that simultaneous infection by ISKNV and other bacteria could influence the large diversity of clinical appearances, which range from inapparent signs to severe symptoms, e.g., extensive hemorrhage. In this study, it remains elusive whether ISKNV or bacterial pathogen is the primary pathogen, and the clear understanding of pathogens interrelation in vivo required further investigation.

Apart from Asian sea bass, ISKNV has been reported in farmed Nile tilapia and ornamental fish in Thailand as well [1, $10,47]$. The clinical appearances of these ISKNV-infected fishes also similar to those observed in this study. The ISKNV from ornamental fish were genetically classified as genotype I [1], based on the MCP gene sequence, similar to the ISKNV of this study. In the previous studies, the area of disease outbreaks was also in the same region (central Thailand) as the ISKNV-positive Asian sea bass samples collected in this study. Therefore, the cross-species transmission between these freshwater farmed fishes, although not yet been documented officially, should be aware and the biosecurity-oriented management should be of concern (particularly in the area with outbreak history) since the sharing of water resources among farms is hardly evitable.

ISKNV was also identified from various marine fish species in other Southeast Asian countries including Indonesia, Vietnam, Malaysia, and Singapore [11, 23, 39, 46]. Most of the ISKNV found in these countries were genotype I, similar to our study, which indicated the widespread of this ISKNV genotype in Southeast Asia. According to the original article describing ISKNV genotyping [15], ISKNV can be classified into three genotypes (I, II, and III) based on the diversity in the MCP gene. These genotypes later assigned into three clusters comprised of RSIV, ISKNV, and TRBIV groups under the same virus species, as described by the International Committee on Taxonomy of Viruses (ICTV, https://talk.ictvonline.org/ictv-reports/ictv_online_report/dsdna-viruses/w/iridoviridae/615/genus-megalocytivirus). To date, the ISKNV genotype II was reported from orbiculate batfish (Platax orbicularis), Banggai cardinalfish (Pterapogon kauderni), and marble goby (Oxyeleotris marmorata) in Indonesia, Japan, USA, and China [32, 43, 49], while Asian sea bass mortality associated with ISKNV genotype II infection was found in Southern China and Vietnam [11, 50]. According to the phylogenetic analysis conducted in this study, the genetic diversity among the current ISKNV isolates was rather small as all the samples are classified as genotype I and shared $100 \%$ sequence homology in both $M C P$ and ATPase genes. MCP and ATPase, as well as DNA polymerase, genes were generally used to determine the genetic relationship of megalocytivirus due to their evolutionary conservation nature [30,32]. However, the relationship between the genetically similar strains cannot be inferred, at least for the current collection of virus isolates, relying on these conserved genes alone. To date, the in-depth epidemiological regarding ISKNV genotype distributed in Thailand and neighboring countries in Southeast Asia is scarce. Thus, the development of an efficacious 'regional' vaccine against ISKNV distributed in Southeast Asia is hardly accomplished unless sufficient epidemiological insight is established. For further investigation, other molecular markers, such as four ankyrin repeat domains [30], offering higher discriminatory power would be added to the phylogenetic comparisons which will determine the intra-genotype diversity of ISKNV on a finer scale.

Isolation of ISKNV from the infected Asian sea bass specimens using GF cell line was successful in this study. Application of GF cell for the propagation of ISKNV simultaneously with nervous necrosis virus has been reported in our previous study [24]. However, the result of this study was slightly inconsistent with another publication in terms of CPE on-set [48]. In the former study, CPE cannot be observed clearly until $14 \mathrm{dpi}$, whereas 5 dpi on-set was found in

Page 13/24 
this study and clearly discerned at $7 \mathrm{dpi}$. The variation in CPE development possibly due to the difference in the initial inoculation dose since this study intentionally selected a specimen with potentially high viral titer (indicated by onetubed snPCR). Recently, the alternative cell line GS-1 originated from orange-spotted grouper (Epinephelus coioides) fibroblast was reported to be ISKNV susceptible and allowed the virus to reach $10^{5.2} \mathrm{TCID}_{50} / \mathrm{ml}$ titer within 7 days, though direct comparison of ISKNV replication kinetic to GF cell has not been described yet [19].

The pathogenicity assay conducted in this study was able to fulfill Koch's postulates and proved that ISKNV was pathogenic to freshwater reared Asian sea bass. The result suggested that the pathogenicity of ISKNV and on-set of mortality depend on the infection dose (Fig. 6). The cumulative mortalities were similar to the previous investigations $(90,77$, and $85.89 \%)$, as well as the on-set of mortalities at $5-9 \mathrm{dpc}[48,50]$. It should be mentioned that the size of the experimental animal used in this study (juvenile, $22 \mathrm{~g}$ weight) was different from the previous report (fingerling, $3.5 \mathrm{~g}$ weight) [48], which suggested that ISKNV was able to cause severe mortality in Asian sea bass at various life stages. Pertaining to clinical appearances, it is worth mentioning that the experimental animals exhibited only the typical darkened body and pale gill, in agreement with those described in the recent study [50]. On the other hand, the obvious external lesions such as scale loss, muscle necrosis, and hemorrhage were observed only from the naturally infected fish. The difference in the clinical manifestations could be due to bacterial pathogens co-infected with ISKNV in natural cases (Table 2). This emphasized that diagnosis of field outbreaks should be performed cautiously and multiple approaches, including pathogen isolation, PCR, and histopathology, should be applied when possible, to get a comprehensive understanding of the disease scenario.

The metagenomic shotgun sequence was able to unveil the draft genome sequence of SDDV directly from the infected specimen, without the need of virus culture, in our recent investigation [28]. In this study, the same analytical approach has been implemented and the complete genomes of ISKNV KU1 and KU2 were reconstructed with the acceptable coverage depth at 47-56x. The genome-scale phylogenetic network (Fig. 3C) showed the reticulation pattern within ISKNV and RSIV groups which implied the possible genetic recombination between the members of these groups. In fact, one of the ISKNV group members, RSIV-Ku, harbored 7\% of genome contents similar to the GSIV-K1 (belonging to RSIV group) which indicated that this strain was ISKNV/RSIV recombinant [42]. Herein, possible recombination between ISKNV KU1/KU2 and other megalocytiviruses was screened using the RDP4 program [35] but no evidence of recombination was found in their genomes (data not shown). Orthology analysis showed a surprisingly high number of unassigned orthogroups (unique genes) among the genomes of ISKNN KU1/KU2, RSIV-Ku, and reference strain. It is predictable that the strain RSIV-Ku, a natural recombinant virus, may possess numerous unique genes since its genome carried a 7.8-kb-long region similar to RSIV genotype II rather than ISKNV [42]. In the case of the ISKNV reference strain, 18 genes were unassigned to any orthologous groups, though the core genome similarity comparing to the ISKNV KU1/KU2 was as high as $99.98 \%$. This could be explained by the difference in genome annotation methods used for CDS prediction in the ISKNV reference strain and KU1/KU2. Protein-coding sequences of the ISKNV reference strain were identified by querying sequences through a protein domain database [17], whereas the unsupervised machine learning algorithm-based program (Prokka) was employed in the case of ISKNV KU1/KU2. Among the non-orthologous genes presented in ISKNV KU1/KU2, the caspase recruitment domain-containing (CARD) protein was identified. This protein was highly similar to those of Angelfish iridovirus AFIV-16, also belongs to ISKNV genotype I [27], isolated from angelfish Pterophyllum scalare in Southeast Asia. CARDs are well-known interaction motifs involved in inflammation and apoptosis regulation [18]. CARD protein has been demonstrated in vitro for apoptosis inhibitory effects in Grouper iridovirus, a member of the genus Ranavirus of the family Iridoviridae [5]. Nevertheless, the role of CARD protein on the molecular pathogenesis of ISKNV, whether it is involved in apoptosis inhibition, remains to be further elucidated. 
Summarily, the homologous strains of ISKNV genotype I have been identified as a causative agent of mass mortalities in freshwater cultured Asian sea bass in the eastern and central Thailand by a combination of histopathology, molecular analyses, and pathogenicity assay. The complete genome of two ISKNV isolates, KU1 and KU2, was obtained using a metagenomics approach. The genome information, as well as the virus archive collected in this study, could be useful for evolutionary analysis and selection of potential genotype I vaccine candidates for the sustainable prevention of ISKNV outbreaks in the future.

\section{Declarations}

\section{Acknowledgments}

This research was supported by the funding from the Center of Excellence on Agricultural Biotechnology, Science and Technology Postgraduate Education and Research Development Office, Office of Higher Education Commission, Ministry of Education (AG-BIO/PERDO-CHE; grant ID. AG-BIO/61-003-010) and Thailand Research Fund under the Research Grant for New Scholar program (grant no. MRG6180054). The authors acknowledge the Center of Excellence for Shrimp Molecular Biology and Biotechnology (CENTEX Shrimp), Mahidol University, for providing technical supports.

\section{Funding}

This research was supported by the funding from the Center of Excellence on Agricultural Biotechnology, Science and Technology Postgraduate Education and Research Development Office, Office of Higher Education Commission, Ministry of Education (AG-BIO/PERDO-CHE; grant ID. AG-BIO/61-003-010) and Thailand Research Fund under the Research Grant for New Scholar program (grant no. MRG6180054).

\section{Conflicts of interest/Competing interests}

The authors declared no conflict of interest.

\section{Availability of data and material}

This manuscript has data included as electronic supplementary material.

\section{Code availability}

Not applicable

\section{Author contributions}




\begin{tabular}{|ll|}
\hline Authors & Contributions \\
\hline Pattarawit Kerddee & Carried out the experiment, wrote the manuscript \\
\hline Nguyen Dinh-Hung & Performed analysis (disease diagnosis) \\
\hline Ha Thanh Dong & Performed the analysis (histopathology, cell culture and qPCR) \\
\hline Ikuo Hirono & Contributed analysis tool (GF cell line) \\
\hline Chayanit Soontara & Performed analysis (disease diagnosis and experimental challenge) \\
\hline Nontawith Areechon & Conceived of overall direction and planning \\
\hline Prapansak Srisapoome & Collected the samples from natural outbreaks \\
\hline Pattanapon Kayansamruaj & Designed experiment, wrote the manuscript \\
\hline
\end{tabular}

\section{Ethics approval}

The animal use protocol conducted in this study was approved by the Institutional Animal Care and Use Committee, Faculty of Fisheries, Kasetsart University (permit ID: ACKU61-FIS-055).

\section{References}

1. Baoprasertkul P, Kaenchan N (2019) Distribution and detection of megalocytivirus in ornamental fish in Thailand. J Fish Environment 43:11-24

2. Barnette P, Labella A, Alonso C, Manchado M, Castro D, Borrego J (2009) The first isolation of Photobacterium damselae subsp. damselae from Asian seabass Lates calcarifer. Fish Pathol 44:47-50

3. Bolger AM, Lohse M, Usadel B (2014) Trimmomatic: a flexible trimmer for Illumina sequence data. Bioinformatics $30: 2114-2120$

4. Bromage ES, Thomas A, Owens L (1999) Streptococcus iniae, a bacterial infection in barramundi Lates calcarifer. Dis Aquat Organ 36:177-181

5. Chen C-W, Wu M-S, Huang Y-J, Lin P-W, Shih C-J, Lin F-P, Chang C-Y (2015) Iridovirus CARD protein inhibits apoptosis through intrinsic and extrinsic pathways. PloS one 10:e0129071

6. Chen J, Toh X, Ong J, Wang Y, Teo XH, Lee B, Wong PS, Khor D, Chong SM, Chee D, Wee A, Wang Y, Ng MK, Tan BH, Huangfu T (2019) Detection and characterization of a novel marine birnavirus isolated from Asian seabass in Singapore. Virol J 16:71

7. Cowan ST, Steel KJ, Barrow GI, Feltham RKA (1993) Cowan and Steel's manual for the identification of medical bacteria, 3rd edn. Cambridge University Press, Cambridge

8. Darling AE, Mau B, Perna NT (2010) progressiveMauve: multiple genome alignment with gene gain, loss and rearrangement. PloS one 5:e11147

9. DOF (2018) Fisheries statistics of Thailand 2018 (available at https://www.fisheries.go.th/strategystat/themeWeb/books/2559/1/yearbook_2559.pdf). In: Fisheries Do (ed)

10. Dong HT, Nguyen VV, Le HD, Sangsuriya P, Jitrakorn S, Saksmerprome V, Senapin S, Rodkhum C (2015) Naturally concurrent infections of bacterial and viral pathogens in disease outbreaks in cultured Nile tilapia (Oreochromis niloticus) farms. Aquaculture 448:427-435 
11. Dong HT, Jitrakorn S, Kayansamruaj P, Pirarat N, Rodkhum C, Rattanarojpong T, Senapin S, Saksmerprome V (2017) Infectious spleen and kidney necrosis disease (ISKND) outbreaks in farmed barramundi (Lates calcarifer) in Vietnam. Fish Shellfish Immunol 68:65-73

12. Dong HT, Taengphu S, Sangsuriya P, Charoensapsri W, Phiwsaiya K, Sornwatana T, Khunrae P, Rattanarojpong T, Senapin S (2017) Recovery of Vibrio harveyi from scale drop and muscle necrosis disease in farmed barramundi, Lates calcarifer in Vietnam. Aquaculture 473:89-96

13. Emms DM, Kelly S (2019) OrthoFinder: phylogenetic orthology inference for comparative genomics. Genome Biol $20: 238$

14. FAO (2021) Cultured Aquatic Species Information Programme. Lates calcarifer. cultured aquatic species information programme. Text by Rimmer, M.A. In: FAO Fisheries Division [online]. Rome. Updated. [Cited 25 March 2021]. (available at: http://www.fao.org/fishery/culturedspecies/Lates_calcarifer/en).

15. Fu X, Li N, Liu L, Lin Q, Wang F, Lai Y, Jiang H, Pan H, Shi C, Wu S (2011) Genotype and host range analysis of infectious spleen and kidney necrosis virus (ISKNV). Virus Genes 42:97-109

16. Grant JR, Stothard P (2008) The CGView Server: a comparative genomics tool for circular genomes. Nucleic Acids Res 36:W181-184

17. He JG, Deng M, Weng SP, Li Z, Zhou SY, Long QX, Wang XZ, Chan SM (2001) Complete genome analysis of the mandarin fish infectious spleen and kidney necrosis iridovirus. Virol 291:126-139

18. Hofmann K, Bucher P, Tschopp J (1997) The CARD domain: a new apoptotic signalling motif. Trends Biochem Sci 22:155-156

19. Huang S-M, Kuo S-T, Kuo H-C, Chang S-K (2018) Assessment of fish iridoviruses using a novel cell line GS-1, derived from the spleen of orange-spotted grouper Epinephelus coioides (Hamilton) and susceptible to ranavirus and megalocytivirus. J Vet Ned Sci 80:1766-1774

20. Huang SM, Tu C, Tseng CH, Huang CC, Chou CC, Kuo HC, Chang SK (2011) Genetic analysis of fish iridoviruses isolated in Taiwan during 2001-2009. Arch Virol 156:1505-1515

21. Humason GL (1979) Animal Tisuue Techiniques, Sanfrancisco, CA

22. Huson DH, Bryant D (2006) Application of phylogenetic networks in evolutionary studies. Mol Biol Evol 23:254267

23. Jeong JB, Kim HY, Jun LJ, Lyu JH, Park NG, Kim JK, Jeong HD (2008) Outbreaks and risks of infectious spleen and kidney necrosis virus disease in freshwater ornamental fishes. Dis Aquat Organ 78:209-215

24. Jitrakorn S, Gangnonngiw W, Bunnontae M, Manajit O, Rattanarojpong T, Chaivisuthangkura P, Dong HT, Saksmerprome V (2020) Infectious cell culture system for concurrent propagation and purification of Megalocytivirus ISKNV and nervous necrosis virus from Asian Sea bass (Lates calcarifer). Aquaculture 520:734931

25. Katoh K, Rozewicki J, Yamada KD (2017) MAFFT online service: multiple sequence alignment, interactive sequence choice and visualization. Brief Bioinform 20:1160-1166

26. Kawakami H, Nakajima K (2002) Cultured fish species affected by red sea bream iridoviral disease from 1996 to 2000. Fish Pathol 37:45-47

27. Kawato Y, Mohr PG, Crane MSJ, Williams LM, Neave MJ, Cummins DM, Dearnley M, Crameri S, Holmes C, Hoad J, Moody NJG (2020) Isolation and characterisation of an ISKNV-genotype megalocytivirus from imported angelfish Pterophyllum scalare. Dis Aquat Organ 140:129-141

28. Kayansamruaj P, Soontara C, Dong HT, Phiwsaiya K, Senapin S (2020) Draft genome sequence of scale drop disease virus (SDDV) retrieved from metagenomic investigation of infected barramundi, Lates calcarifer (Bloch, 
1790). J Fish Dis 43:1287-1298

29. Kerddee P, Dong HT, Chokmangmeepisarn P, Rodkhum C, Srisapoome P, Areechon N, Del-Pozo J, Kayansamruaj P (2020) Simultaneous detection of scale drop disease virus and Flavobacterium columnare from diseased freshwater-reared barramundi Lates calcarifer. Dis Aquat Organ 140:119-128

30. Kim KI, Lee ES, Do JW, Hwang SD, Cho M, Jung SH, Jee BY, Kwon WJ, Do Jeong H (2019) Genetic diversity of Megalocytivirus from cultured fish in Korea. Aquaculture 509:16-22

31. Kumar S, Stecher G, Li M, Knyaz C, Tamura K (2018) MEGA X: Molecular Evolutionary Genetics Analysis across Computing Platforms. Mol Biol Evol 35:1547-1549

32. Kurita J, Nakajima K (2012) Megalocytiviruses. Viruses 4:521-538

33. Langmead B, Salzberg SL (2012) Fast gapped-read alignment with Bowtie 2. Nat Methods 9:357-359

34. Li D, Liu CM, Luo R, Sadakane K, Lam TW (2015) MEGAHIT: an ultra-fast single-node solution for large and complex metagenomics assembly via succinct de Bruijn graph. Bioinformatics 31:1674-1676

35. Martin DP, Murrell B, Golden M, Khoosal A, Muhire B (2015) RDP4: Detection and analysis of recombination patterns in virus genomes. Virus Evol 1:vev003

36. Meemetta W, Domingos JA, Dong HT, Senapin S (2020) Development of a SYBR Green quantitative PCR assay for detection of Lates calcarifer herpesvirus (LCHV) in farmed barramundi. J Virol Methods 285:113920

37. Menzel P, Ng KL, Krogh A (2016) Fast and sensitive taxonomic classification for metagenomics with Kaiju. Nat Commun 7:11257

38. Parameswaran V, Kumar SR, Ahmed VPI, Hameed ASS (2008) A fish nodavirus associated with mass mortality in hatchery-reared Asian Sea bass, Lates calcarifer. Aquaculture 275:366-369

39. Sah Putra B, Hick PM, Hall E, Whittington RJ, Khairul R, Evarianti, Nurbariah, Becker JA (2020) Prevalence of infectious spleen and kidney necrosis virus (ISKNV), nervous necrosis virus (NNV) and ectoparasites in juvenile Epinephelus spp. farmed in Aceh, Indonesia. Pathogens 9

40. Sambrook J, Russell RW (2001) Molecular cloning: A laboratory manual, 3rd edn, 3rd edn. Cold spring harbor laboratory press, NY: Cold spring harbor

41. Senapin S, Dong HT, Meemetta W, Gangnonngiw W, Sangsuriya P, Vanichviriyakit R, Sonthi M, Nuangsaeng B (2019) Mortality from scale drop disease in farmed Lates calcarifer in Southeast Asia. J Fish Dis 42:119-127

42. Shiu JY, Hong JR, Ku CC, Wen CM (2018) Complete genome sequence and phylogenetic analysis of megalocytivirus RSIV-Ku: A natural recombination infectious spleen and kidney necrosis virus. Arch Virol 163:1037-1042

43. Sriwanayos P, Francis-Floyd R, Stidworthy MF, Petty BD, Kelley K, Waltzek TB (2013) Megalocytivirus infection in orbiculate batfish Platax orbicularis. Dis Aquat Organ 105:1-8

44. Starliper C (2008) General and specialized media routinely employed for primary isolation of bacterial pathogens of fishes. J Wildl Dis 44:121-132

45. Subramaniam K, Shariff M, Omar AR, Hair-Bejo M (2012) Megalocytivirus infection in fish. Rev Aquac 4:221-233

46. Subramaniam K, Shariff M, Omar AR, Hair-Bejo M, Ong BL (2014) Detection and molecular characterization of infectious spleen and kidney necrosis virus from major ornamental fish breeding states in Peninsular Malaysia. J Fish Dis 37:609-618

47. Suebsing R, Pradeep PJ, Jitrakorn S, Sirithammajak S, Kampeera J, Turner WA, Saksmerprome V, Withyachumnarnkul B, Kiatpathomchai W (2016) Detection of natural infection of infectious spleen and kidney necrosis virus in farmed tilapia by hydroxynapthol blue-loop-mediated isothermal amplification assay. $\mathrm{J}$ Appl Microbiol 121:55-67

Page $18 / 24$ 
48. Thanasaksiri K, Takano R, Fukuda K, Chaweepack T, Wongtavatchai J (2019) Identification of infectious spleen and kidney necrosis virus from farmed barramundi Lates calcarifer in Thailand and study of its pathogenicity. Aquaculture 500:188-191

49. Wang Q, Zeng WW, Li KB, Chang OQ, Liu C, Wu GH, Shi CB, Wu SQ (2011) Outbreaks of an iridovirus in marbled sleepy goby, Oxyeleotris marmoratus (Bleeker), cultured in southern China. J Fish Dis 34:399-402

50. Zhu Z, Duan C, Li Y, Huang C, Weng S, He J, Dong C (2021) Pathogenicity and histopathology of infectious spleen and kidney necrosis virus genotype II (ISKNV-II) recovering from mass mortality of farmed Asian seabass, Lates calcarifer, in Southern China. Aquaculture 534:736326

\section{Figures}
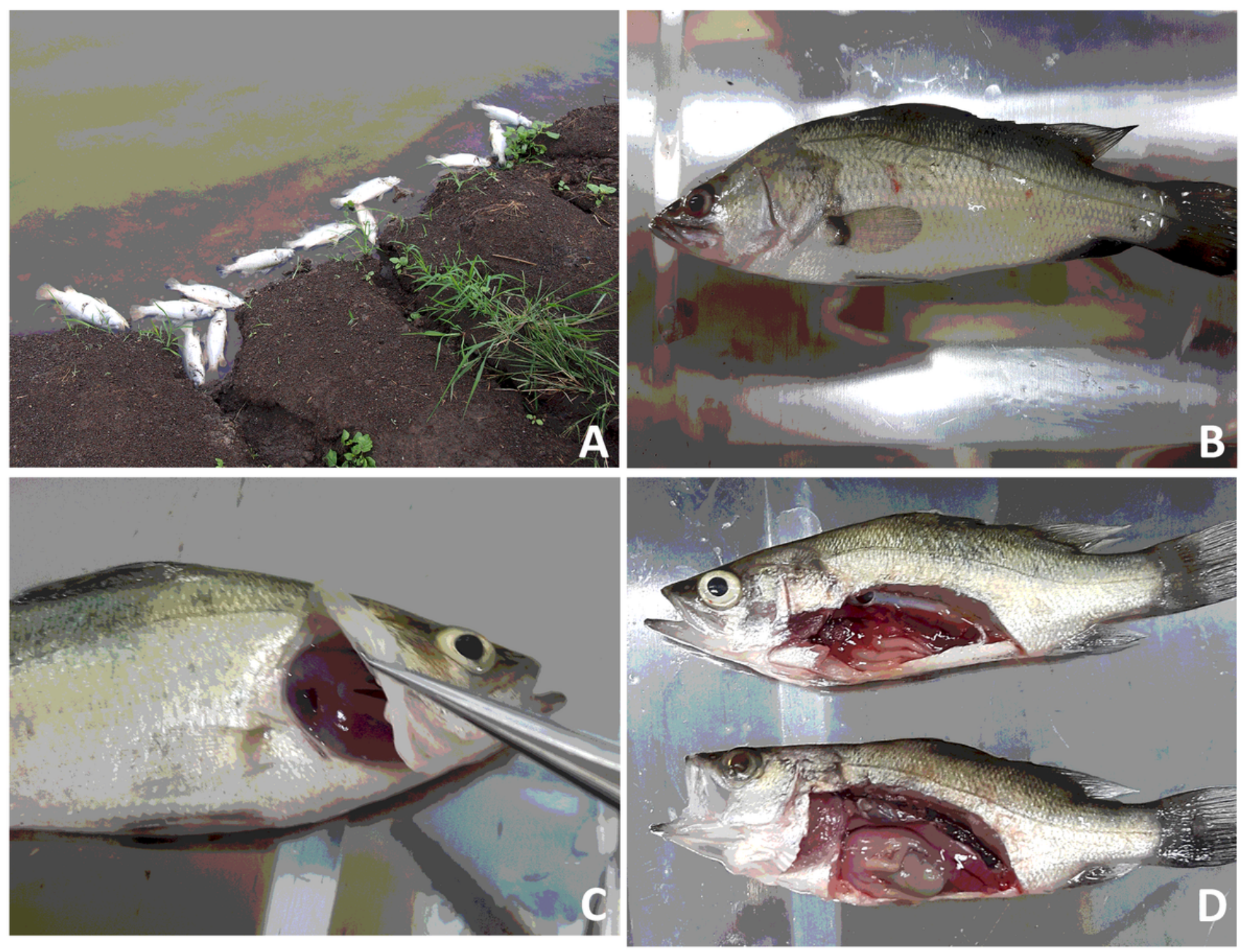

\section{Figure 1}

Macroscopic appearances of Asian sea bass naturally infected with ISKNV. (A) Aggregation of dead fish around the bank was commonly seen in the affected pond. (B) Affected fish exhibited darkened body with hemorrhage at skin and eyes, (C) pale gills. (D) Internally, swollen spleen and hemorrhage at liver and trunk kidney were observed often in moribund fish. 

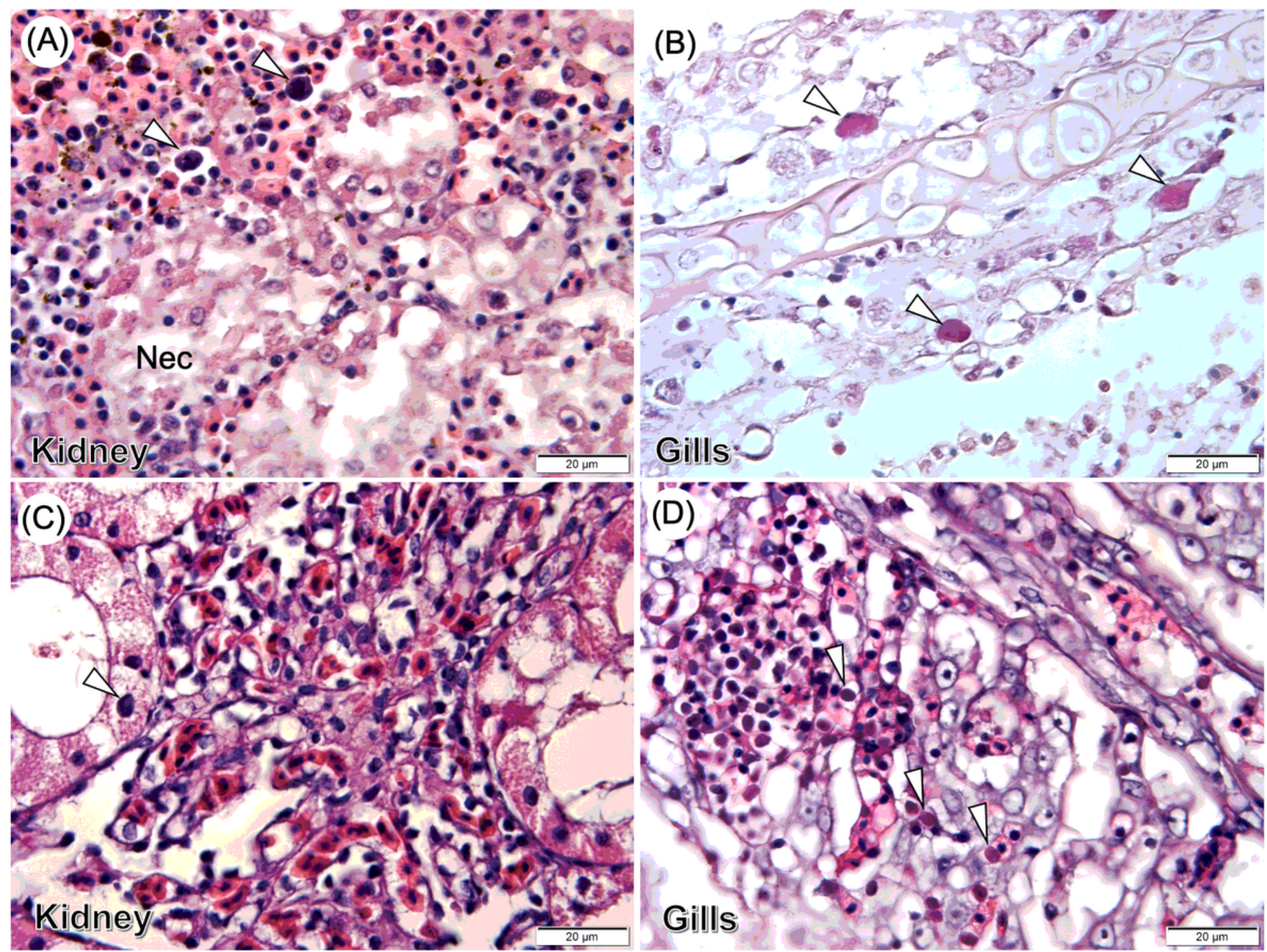

Figure 2

Histopathological appearances in trunk kidney and gill of Asian sea bass naturally infected with ISKNV (A, B) similar to those observed in experimentally infected fish (C, D). Head arrows, basophilic inclusion bodies (megalocytosis); Nec, necrosis of kidney tubules. 

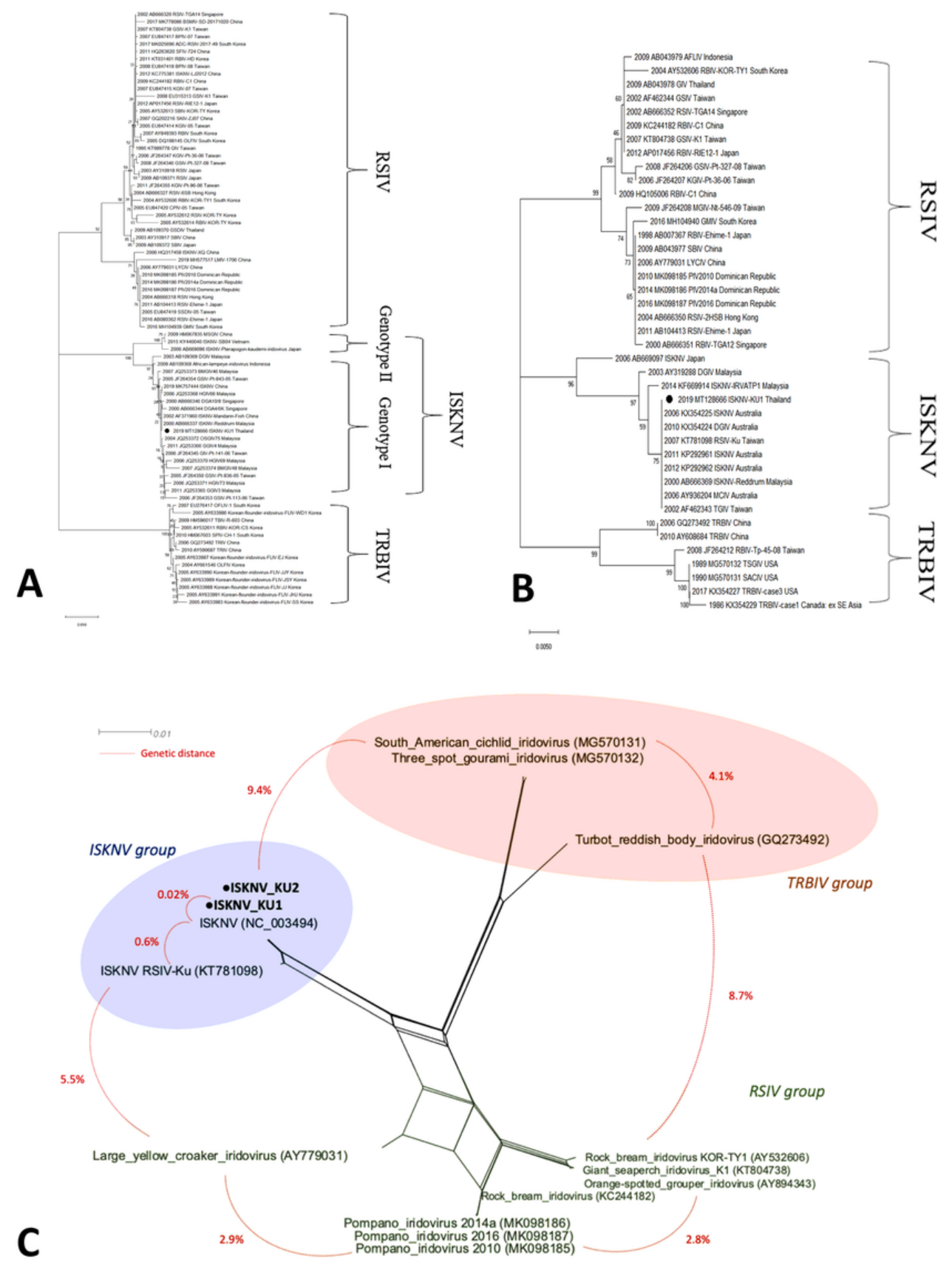

\section{Figure 3}

Phylogenetic analyses of megalocytiviruses comprised of ISKNV, RSIV and, TRBIV. Maximum likelihood tree generated from (A) MCP and (B) ATPase genes of the viruses. (C) Neighbor-net split graph generated from whole-genome alignment. Genetic distance between genomes was demonstrated as percent substitution per nucleotide (labeled in red and dashed line). The ISKNV recovered in this study was marked by a black circle. The number at the nodes of the tree represent the bootstrap value, whereas scale represent the rate of substitution per nucleotide. 


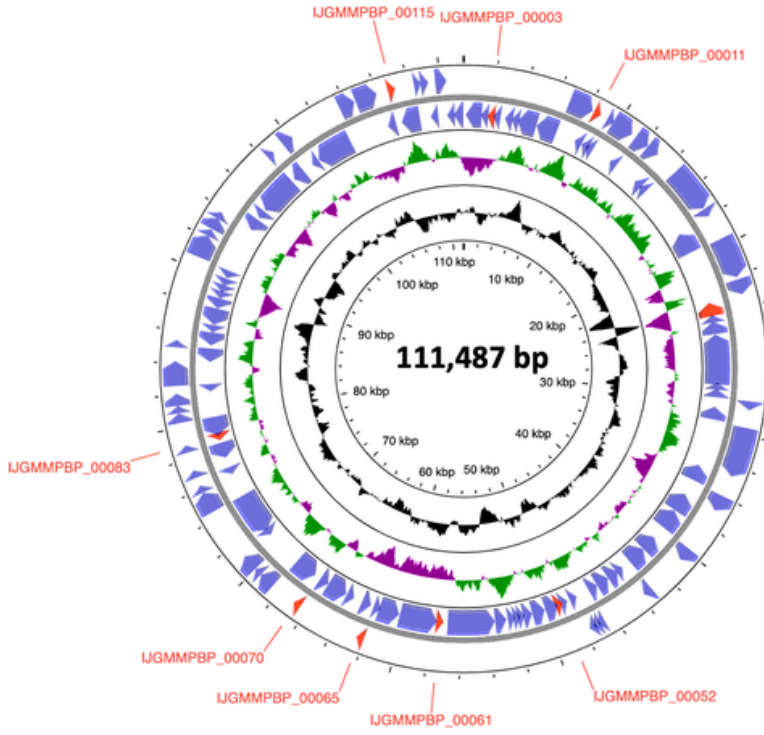

ISKNV strain KU1

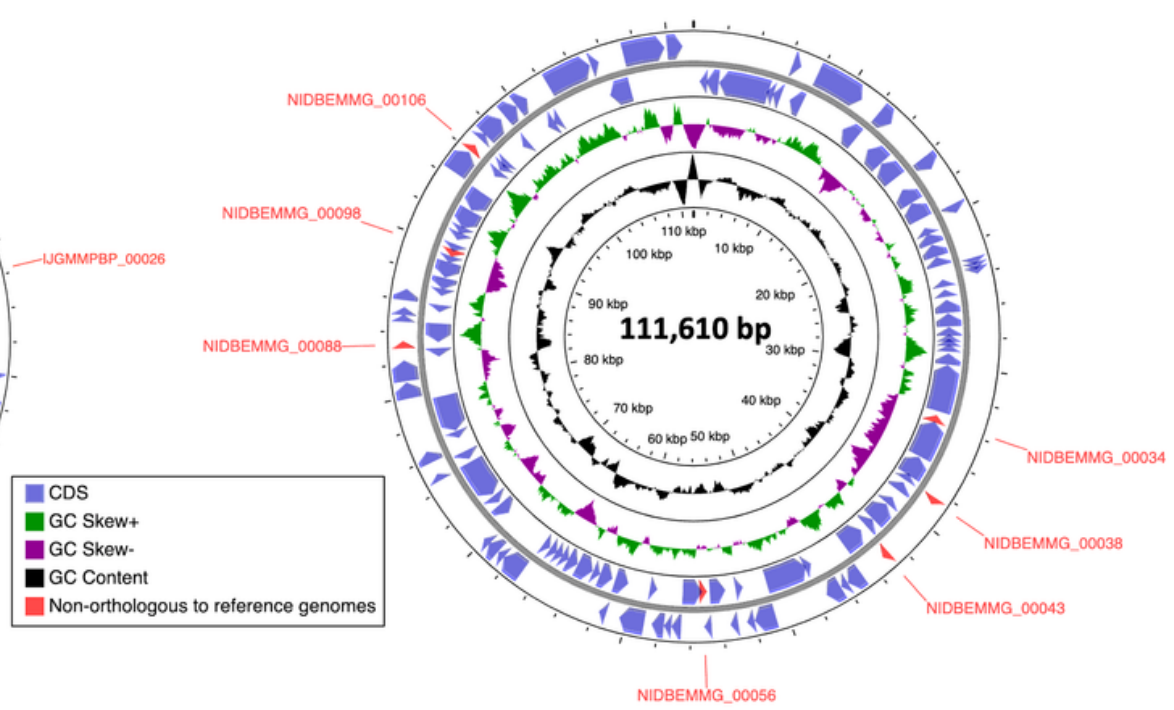

ISKNV strain KU2

\section{Figure 4}

Circular map of ISKNV KU1, KU2 created by CGView. Red arrows in CDS rings represent non-orthologs, comparing to the ISKNV reference strain and ISKNV strain RSIV-Ku, with locus-tag labeled. 


\section{Control GF cells}

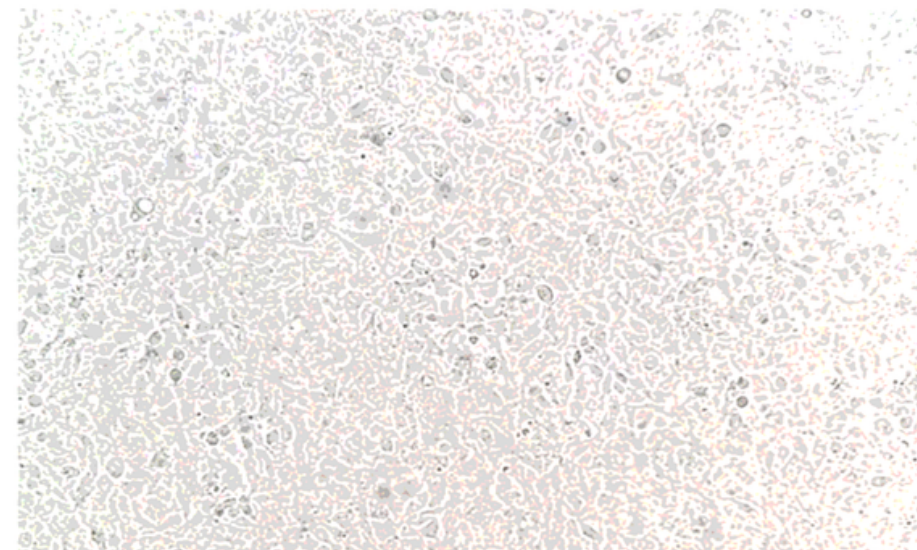

\section{$5 \mathrm{dpi}$}

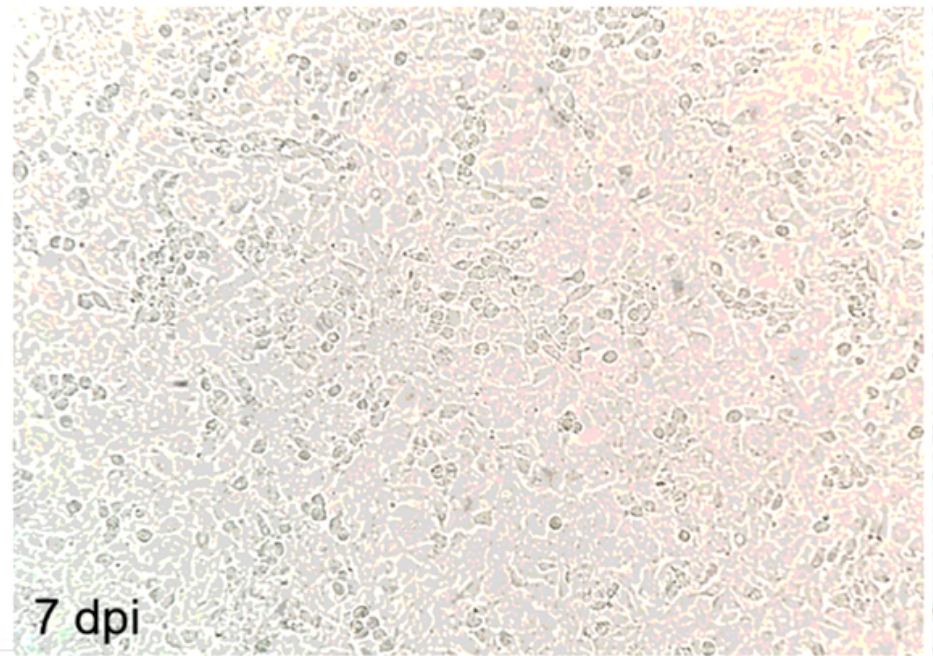

ISKNV infected GF cells
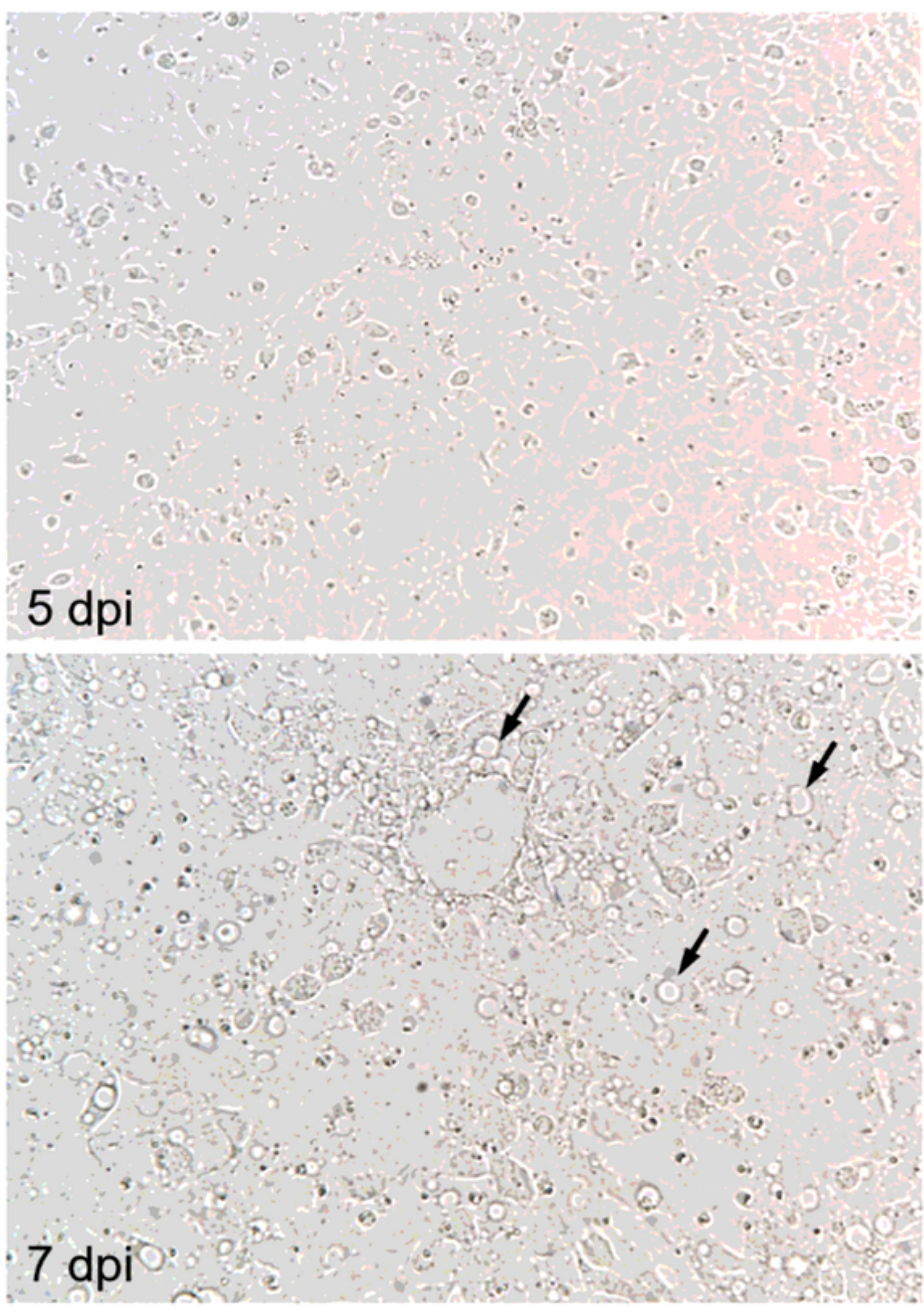

\section{Figure 5}

Photomicrograph of Grunt fin (GF) cell monolayer inoculated with filtrate extracted from the tissue of ISKNV-infected (right panel) Asian sea bass. Control GF cells (left panel) were culture with conditions identical to those of ISKNVinfected cells. Arrows indicated cytopathic effect (vacuolization) observed in the ISKNV-infected cells at 7 days postinoculation. 


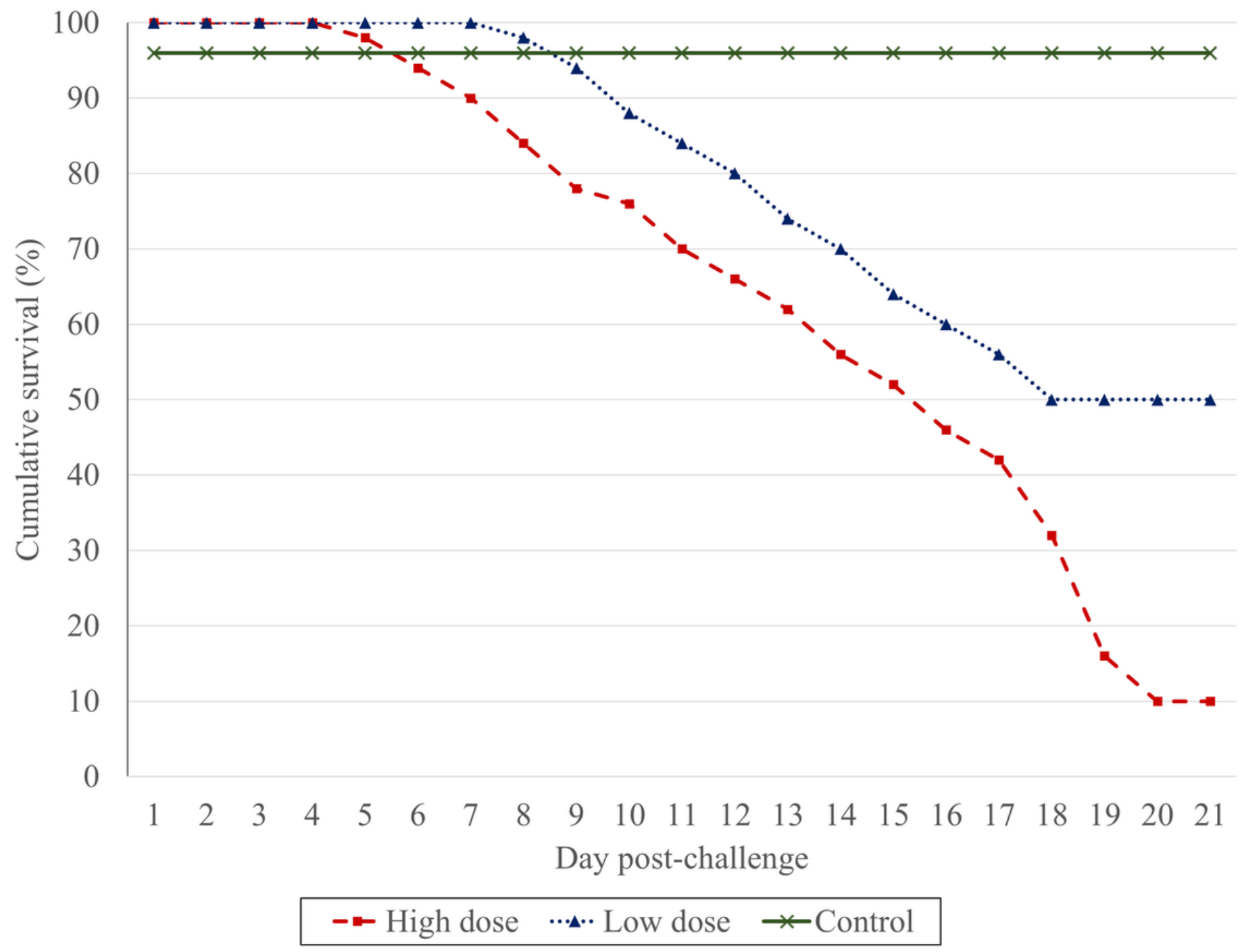

Figure 6

Cumulative survival of Asian sea bass experimentally infected with ISKNV high dose $(2.9 \otimes 105$ virus copy numbers per fish) and low dose (red line, $2.9 \otimes 103$ virus copy numbers per fish). Fish in the control group were inoculated with a sterile cell culture medium.

\section{Supplementary Files}

This is a list of supplementary files associated with this preprint. Click to download.

- supplementary.03.docx 